Vol u m e 14 N u m ber 1 P a ges 14-25, 20 020

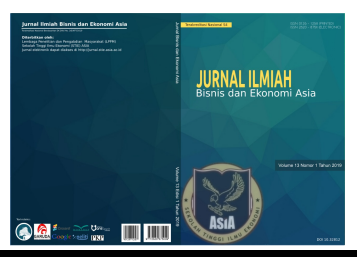

\title{
PENGARUH PENGELUARAN PER KAPITA DAN BELANJA KESEHATAN TERHADAP ANGKA KESAKITAN DI KABUPATEN/KOTA SE-PULAU JAWA
}

\author{
Dania Setira Amru ${ }^{1 *}$, Estro Dariatno Sihaloho \\ ${ }_{1,2}$ Universitas Padjajaran, Indonesia
}

INFO ARTIKEL

DOI:10.32812/jibeka.v14i1.135

ISSN-P: 0126-1258

ISSN-E: 2620-875X

Keywords: Mordibity Rate, Health Expenditure, Expenditure per Capita

\begin{abstract}
This paper focuses on two objectives. First, this paper estimates the effect of expenditure per capita on mordibity rate in regencies and cities in Java Island. Second, this paper estimates the effect of health expenditure or health budget allocation on mordibity rate in regencies and cities in Java Island. Mordibity rate is a percentage of people who is sick in some area at a certain period of time. This paper uses a Cross Section Data OLS. This paper uses cross section data of 113 Regencies and Cities in Java Island from 2018. This paper use mordibity rate as the dependent variable, expenditure per capita and health budget allocation as the independent variable. The result of this paper shows that Cross Section Data OLS estimate expenditure per capita has a negative and significant effect on mordibity effect. Cross section data OLS estimate health budget allocation has a negative and not significant effect on mordibity rate in regencies and cities in Java Island.
\end{abstract}

\section{ABSTRAK}

Penelitian ini berfokus pada dua tujuan. Pertama, penelitian ini mengestimasi efek pengeluaran per kapita terhadap angka kesakitan di kabupaten dan kota di Pulau Jawa. Kedua, penelitian ini mengestimasi efek dari belanja kesehatan alokasi anggaran dana kesehatan terhadap angka kesakitan di kabupaten dan kota di Pulau Jawa. Angka Kesakitan adalah persentase dari masyarakat yang sakit pada suatu daerah dan periode waktu tertentu. Penelitian ini menggunakan data cross section OLS. Penelitian ini menggunakan data cross section dari 113 kabupaten dan kota di Pulau Jawa pada tahun 2018. Penelitian ini menggunakan angka kesakitan sebagai variabel dependen, pengeluaran per kapita dan alokasi dana kesehatan sebagai variabel independen. Hasil dari penelitian ini menunjukan data cross section OLS mengestimasi pengeluaran per kapita mempunyai pengaruh yang negatif dan signifikan terhadap angka kesakitan. Data Cross section OLS mengestimasi alokasi dana kesehatan mempunyai pengaruh yang negatif.dan tidak signifikan terhadap angka kesakitan di kabupaten dan kota di pulau Jawa. 


\section{Pendahuluan}

Indonesia merupakan Negara berkembang yang mana sedang berjalan untuk menjadi Negara maju. Tentunya dalam hal itu ditemui berbagai permasalahan yang harus diselesaikan. Kesejahteraan sosial merupakan salah satu concern terbesar pemerintah Indonesia saat ini. Sesuai dengan teks Pembukaan Undang-Undang Dasar Tahun 1945 memajukan kesejahteraan segenap masyarakat Indonesia merupakan cita-cita dari Negeri ini dan juga merupakan hak asasi dari setiap manusia. Sejahtera menurut (Notowidagdo, 2016) adalah kondisi aman, sentosa dan berkecukupan serta selamat. Berdasarkan UU no 11 tahun 2009 indikator mengukur kesejahteraan sosial adalah dengan melihat tercukupi atau terpenuhinya kebutuhan-kebutuhan seperti kebutuhan materil, kebutuhan spiritual serta sehat jasmani dan rohani. Dengan penjelasan tersebut dapat disimpulkan bahwa kesehatan masyarakat merupakan salah satu indikator kesejahteraan sosial.

Pulau Jawa merupakan salah satu pulaui dengan jumlah penduduk terbesar di Indonesia. Melihat kemajuan pulau Jawa dibidang teknologi, sumber daya manusia, sumber daya alam, dan yang lainnya tetapi juga semakin lama bermunculan permasalahanpermasalahan yang kompleks terutama dibidang kesehatan (Amrullah, 2015).Dalam melahirkan sumber daya manusia yang berkualitas dibutuhkan sarana dan prasarana dalam mewujudkannya seperti penanaman modal dalam bidang pendidikan dan kesehatan, maka dari itu sangat diperlukan peran besar pemerintah (Muliza, 2017).

\section{Gambar 1. Persentase Penduduk Yang Mempunyai Keluhan Kesehatan Menurut Provinsi di Pulau Jawa Tahun 2016-2017}

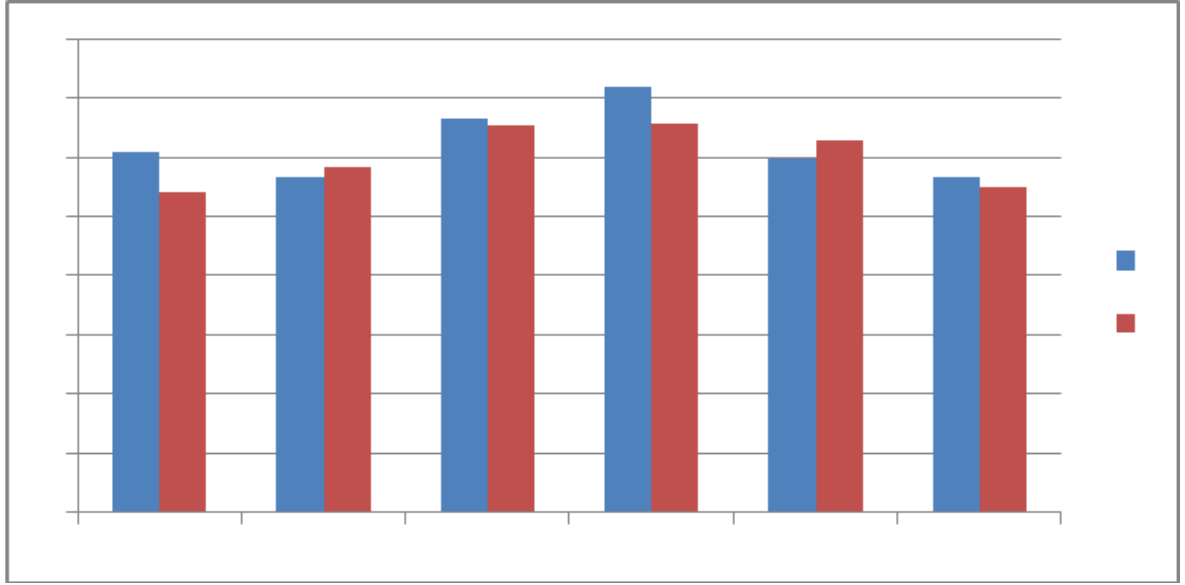

Sumber: (Badan Pusat Statistik: Statistik Kesejahteraan Rakyat Provinsi, 2018)

Kesehatan menurut (Sitorus, 2017) adalah hak asasi setiap individu dan juga dapat diartikan sebagai investasi karena apabila seseorang sehat maka ia akan lebih produktif dan akan menghasilkan output pekerjaan yang lebih banyak maka dari itu diperlukan perhatian khusus baik dari pemerintah maupun setiap masyarakat terutama masyarakat Indonesia. Pembangunan dibidang kesehatan merupakan suatu usaha pemerintah dalam memenuhi kebutuhan dasar dan hak asasi masyarakat yakni memperoleh pelayanan dan fasilitas kesehatan yang memadai dan baik serta dapat memberikan manfaat sebesar-besarnya secara langsung yang mana membantu menurunkan angka kesakitan di daerah kabupaten atau kotaa tersebut (Suarsih, 2017).

Angka Kesakitan menurut UU Kesehatan dan Praktik kedokteran nomor 28 adalah nilai atau presentase masyarakat yang merupakan penderita sakit yang terjadi disuatu daerah pada periode waktu tertentu. Angka kesakitan dalam (Budiarto, 2001) dijelaskan sebagai indeks yang penting dalam menentukan derajat kesehatan masyarakat. Angka kesakitan merupakan indikator yang kuat dalam menghitung angka kematian dan bagaimana kinerja proses implementasi program penurunan tingkat kematian dan kesakitan di suatu daerah. Berdasarkan (Hidayat, 2008) angka kesakitan dapat dipengaruhi oleh berbagai macam faktor yakni bagaimana kualitas pelayanan kesehatan di daerah tersebut, kualitas gizi masyarakat, faktor sosial dan faktor ekonomi. Angka kesakitan memperlihatkan 
keadaan sesungguhnya dikarenakan mempunyai hubungan yang sangat signifikan terhadap penyebab kemiskinan, kondisi tempat tinggal, kondisi air minum layak, dan kualitas pelayanan kesehatan di suatu daerah (Kardjati, 1985). Status gizi dapat membantu kita untuk menyadari lebih dini segala kemungkinan resiko terjangkit penyakit. Setiap daerah kabupaten atau kota mempunyai permasalahan mengenai pangan dan kualitas gizi makanan berbeda dengan daerah lain (Augustyn, 2002).

Kualitas gizi masyarakat bergantung pada pendapatan yang mereka hasilkan atau pengeluaran yang mereka rela korbankan untuk membeli makanan serta minuman yang sehat. Kualitas pelayanan kesehatan di daerah tersebut juga bisa di pengaruhi oleh bagaimana kualitas tenaga kerja kesehatan serta berapa banyak dana yang pemerintah daerah alokasikan untuk memenuhi pelayanan kesehatan masyarakat. Zat gizi (Soenardi, 2010) adalah unsur yang terdapat dari baik makanan atau minuman yang kita konsumsi, zat gizi ini seperti protein, karbohidrat, lemak, vitamin dan mineral yang mana diperlukan untuk menjaga diri agar tetap sehat. Sedangkan menurut (Marmi, 2013) zat gizi adalah ikatan atau unsur kimia yang diperlukan sebagai penghasil energi untuk menjaga metabolism tubuh sehingga tidak mudah terjangkit penyakit.

Menurut laporan The Legatum Prosperity Index 2017 Indonesia berada diurutan 101 dari 149 negara jika dilihat dari indeks kesehatannya. Apabila ingin melihat tingkat kesehatan disuatu daerah dapat melihatnya melalui data angka kesakitan daerah tersebut, semakin tinggi angka kesakitan di suatu daerah maka semakin rendah kualitas kesehatan dari masyarakat daerah tersebut. Salah satu peran pemerintah dalam menurunkan angka kesakitan disuatu daerah yakni dengan membuat anggaran belanja kesehatan dan memaksimalkan fungsinya. Dalam (Olivia, 2010) dijelaskan bahwa mencapai penurunan angka kesakitan di suatu daerah, pembiayaan kesehatan merupakan faktor terpenting yang mempengaruhi angka kesakitan atau kualitas kesehatan di suatu daerah. Alokasi dana kesehatan daerah menjadi masalah di sebagian daerah kabupaten atau kota di Indonesia walaupun kesehatan menjadi prioritas utama hampir di seluruh wilayah Indonesia terutama Jawa Barat (Handayani, 2016). Alokasi dana kesehatan dari APBN atau Anggaran Pendapatan dan Belanja Negara digunakan untuk pembangunan fisik fasilitas kesehatan yang akan menjadi investasi fisik, Kemampuan pemerintah dalam mengalokasikan anggaran untuk dana pembangunan kesehatan bergantung dari besarnya pemasukan daerah tersebut (Aryani, 2007).

Gambar 2. Persentase Belanja Kesehatan Pemerintah Pusat terhadap APBN Tahun 2016-2018.

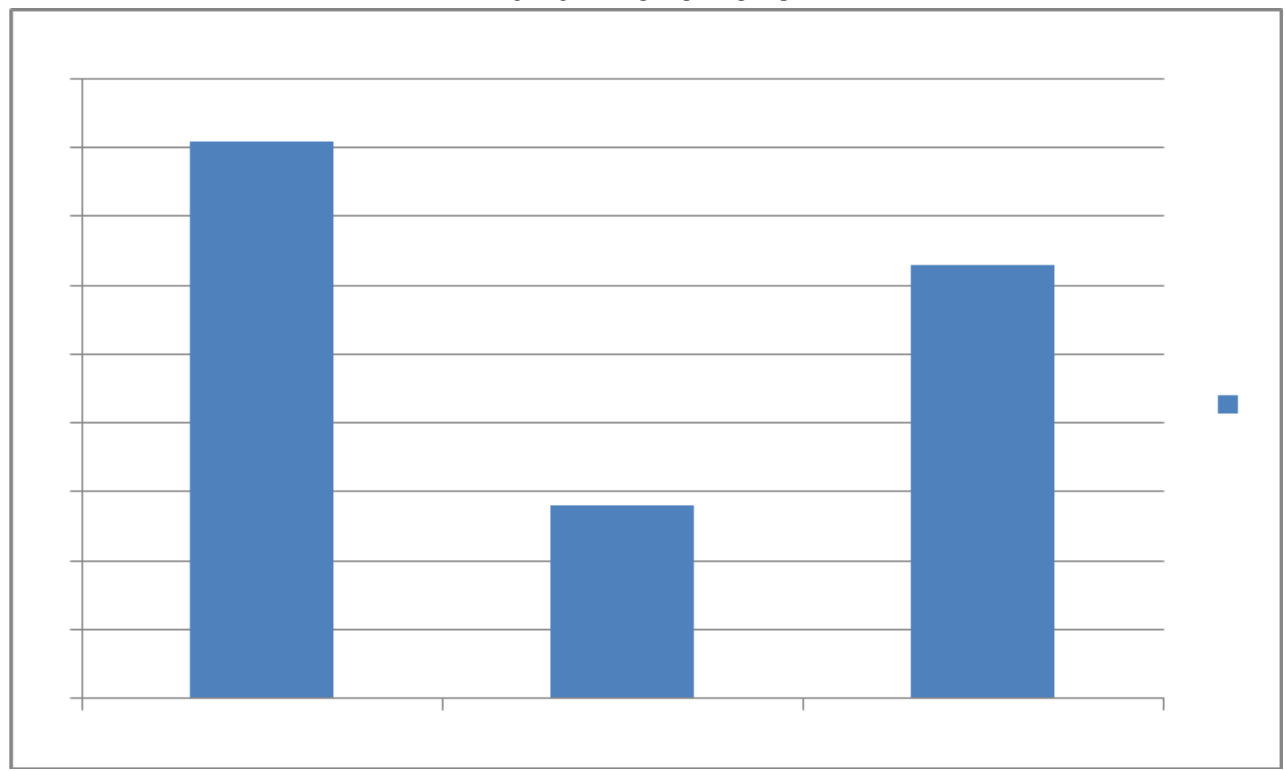

Sumber:(Kementerian Keuangan, 2017, 2018, 2019) 
Gambar 2 menunjukkan pada tahun 2017 persentase belanja kesehatan pemerintah pusat terhadap APBN mengalami penurunan menjadi $60.8 \%$ yang sebelumnya sebesar 66.1\%. Kemudian pada tahun 2018 mengalami kenaikan daripada tahun 2017 adalah sebesar 64.3\%. Dijelaskan pula dalam (Sulastomo, 2007) bahwa kenaikan belanja kesehatan ini dapat dipengaruhi oleh berbagai faktor seperti pembayaran jasa pelayanan kesehatan dan penggunaan teknologi yang berlebihan.

Pengeluaran untuk konsumsi adalah biaya yang dikeluarkan akibat belanja yang dilakukan baik oleh individu, pemerintah dan swasta (Alisjahbana, 2003). Pengeluaran konsumsi mempunyai hubungan yang positif dengan pendapatan seseorang, semakin besar pendapatannya maka semakin besar pula pengeluarannya. Pengeluaran suatu rumah tangga merupakan indikator kemampuan mereka dalam membeli atau mengkonsumsi pangan dan non pangan dalam keluarga. Pendapatan seseorang merupakan peranan penting dalam pemenuhan kebutuhan hidup sehari-hari yang mana pendapatan itu sebagai tolak ukur kemampuan masyarakat dalam memenuhi kesejahteraan hidupnya (Mulazimmah, 2017).

Dijelaskan dalam (Arida, 2015) pengeluaran per kapita adalah pengeluaran yang bukan hanya pengeluaran beras tetapi juga pengeluaran untuk makanan lain dan pengeluaran untuk barang dan jasa lainnya. Kemampuan suatu rumah tangga dalam memenuhi kebutuhan pangan dan non pangannya dapat dilihat dari besarnya pendapatannya (Tuankotta, 2012). Berdasarkan (Syamsurijal, 2008) antara pendapatan atau kesejahteraan mempunyai hubungan yang unidirectional terhadap kesehatan, maksudnya adalah perbaikan kondisi kesejahteraan yang mana akan mengarah pada perbaikan kondisi perekonomian akan akan membawa perubahan yakni perbaikan kualitas kesehatan. Pengeluaran konsumsi ini dapat digolongkan sebagai pengeluaran belanja makanan dan pengeluaran belanja non makanan. Dijelaskan pula dalam (Alisjahbana, 2003) bahwa semakin rendah tingkat pengeluaran konsumsi masyarakat maka akan semakin rendah pula dominan alokasinya untuk belanja makanan. Seperti yang dijelaskan pada (Hidayat, 2008) sebelumnya pada bahwa pendapatan seseorang yang mana berbanding lurus dengan pengeluaran itu berdampak pada bagaimana kualitas gizi makanan yang kita konsumsi. Ketika seseorang mengkonsumsi makanan dengan gizi yang seimbang dan baik maka ada kemungkinan kecil orang tersebut akan terjangkit penyakit.

Belanja kesehatan adalah jenis anggaran belanja pemerintah daerah yang digunakan untuk membeli fasilitas baik seperti rumah sakit, subsidi obat atau membayar pekerja rumah sakit atau posyandu atau apapun dibidang kesehatan di daerah kabupaten atau kota (Mulazimmah, 2017). Dapat diamati biaya kesehatan semakin lama semakin tinggi, hal ini dikarenakan masyarakat semakin sadar betapa pentingnya kesehatan dan bagaimana penyakit membawa banyak dampak buruk bagi kehidupan mereka. Dijelaskan dalam (Handayani, 2016) bahwa dalam menyediakan pelayanan kesehatan yang baik pemerintah membutuhkan suntikan dana untuk dijadikan sebagai anggaran alokasi dana kesehatan, dana tersebut dapat berasal dari pemerintah itu sendiri maupun masyarakat dan swasta. Tetapi dijelaskan dalam (Sulastomo, 2007) bahwa tingginya belanja kesehatan belum pasti memberi pengaruh tingkat kesehatan yang tinggi.

Sesuai dengan Pancasila sila ke-5 bahwa pemerintah harus menjamin terwujudnya kesejahteraan sosial masyarakat Indonesia, salah satunya dengan memenuhi pelayanan kesehatan yang baik. Dalam (Tuankotta, 2012) jenis pelayanan kesehatan dibedakan menjadi dua jenis yakni pelayanan kesehatan primer dan pelayanan kesehatan sekunder. Pelayanan kesehatan primer itu diberikan saat masyarakat baru saja mengalami gangguan kesehatan atau kecelakaan, sedangkan pelayanan kesehatan sekunder adalah seperti penyediaan fasilitas kesehatan rumah sakit sebagai tempat rawat inap. Salah satu bentuk memenuhi pelayanan kesehatan adalah dengan membuat dana alokasi daerah dibidang kesehatan agar dapat menyediakan fasilitas kesehatan yang optimal dan efektif. Dalam rangka mewujudkan kesejahteraan sosial terutama dibidang kesehatan maka diperlukan pembiayaan, besarnya pembiayaan tersebut tergantung pada komitmen pemerintah daerah tersebut (Handayani, 2016). Belanja Kesehatan seperti yang dijelaskan dalam (Mulazimmah, 2017) adalah jenis belanja daerah yang digunakan oleh pemerintah daerah 
kabupaten atau kota dalam rangka mendanai urusan pemerintah yang menjadi kewenangan pemerintah daerah tersebut yakni pembangunan kesehatan.

Berdasarkan (Efendi, 2009) sumber dana alokasi kesehatan dapat diperoleh dari berbagai macam sumber, mulai dari pemerintah pusat, swasta dan lain-lain. Alokasi dana kesehatan juga dapat diperoleh dari masyarakat misalnya dalam bentuk biaya langsung perawatan kesehatan, investasi dibidang pelayanan kesehatan serta dalam bentuk asuransi di bidang kesehatan. Dijelaskan dalam (Rachmat, 2016) bahwa dana pemerintah untuk kesehatan ditujukan untuk membiayai fasilias kesehatan primer, sekunder dan tersier. Pemanfaatan alokasi dana kesehatan diimplementasikan dengan memperhatikan berbagai macam aspek seperti teknis dan pengalokasiannya sesuai dengan apa yang ditujukan secara efisien dan efektif yang mana perlu dilakukan secara transparan. Pengalokasian dana kesehatan atau pembiayaan fasilitas kesehatan yang lancar sangat mempengaruhi kualitas penyediaan atau pelayanan kesehatan masyarakat dan juga pembiayaan fasilitas kesehatan yang diberikan ke pemerintah daerah adalah upaya untuk mengurangi kesenjangan dibidang kesehatan antar daerah di seluruh Indonesia. Menurut WHO dalam (Sitorus, 2017) bahwa untuk mencapai angka kesehatan yang ideal atau angka kesakitan yang rendah diperlukan anggaran minimal $15 \%$ sampai $20 \%$ dari APBN. Dijelaskan pula bahwa anggaran yang tinggi ini diperlukan karena memang seharusnya kesehatan menjadi concern yang harus diprioritaskan oleh pemerintah. Dan dijelaskan pula bahwa untuk melihat seberapa besarnya komitmen pemerintah daerah kabupaten atau kota terhadap pembangunan kesehatannya dapat dilihat melalui presentase anggaran kesehatannya, apabila presentase anggaran kesehatannya tinggi atau besar maka komitmen pemerintah daerah tersebut juga tinggi terhadap pembangunan kesehatannya. Ketika kualitas fasilitas kesehatan di suatu daerah baik akan menyebabkan penurunan angka kesakitan dikarenakan kualitas kesehatan masyarakat di daerah tersebut sudah terjamin.

Menurut (Handayani, 2016) terpenuhinya dana kesehatan menjadi penting dengan penerapan desentralisasi pelayanan kesehatan yang diperlukan penetapan kebijakan dan strategi alokasi dana program-program kesehatan di suatu daerah. Alokasi dana kesehatan terdiri atas anggaran pembangunan kesehatan atau belanja rutin dan anggaran rutin kesehatan yang merupakan belanja tidak langsung. Dijelaskan dalam (Tuankotta, 2012) bahwa pola hidup suatu masyarakat daerah dengan tidak tercukupinya konsumsi akan menaikkan angka kesakitan daerah tersebut yang mana akan berpengaruh terhadap kualitas masyarakat sekitar, semakin tinggi angka kesakitan semakin tidak produktif. Kualitas kesehatan disuatu daerah dapat ditentukan dengan bagaimana konsumsi pangannya atau makanannya, konsumsi pangan adalah jumlah, macam dan seberapa seringnya makanan yang dikonsumsi sehari-hari.

Pangan merupakan bahan makanan yang mana akan diolah menjadi makanan yang siap dikonsumsi oleh masyarakat. Jika makanannya berkualitas bagus maka mengandung banyak gizi didalamnya. Status gizi dalam penjelasan (Prasetyo, 2013) adalah keadaan dimana seimbangnya asupan dan kebutuhan terhadap gizi. Apabila status gizinya kurang baik berarti terdapat kebutuhan terhadap gizi yang belum terpenuhi. Gizi dalam (Tuankotta, 2012) mempunyai banyak fungsi atau manfaat bagi tubuh kita, yakni sebagai sumber energi, penyeimbang metabolisme dan kadar air dalam tubuh, mengobati jaringan sel yang rusak dan sebagai pertahanan tubuh agar tidak mudah terjangkit suatu penyakit.

\section{Metode Penelitian}

Metode analisis yang digunakan dalam penelitian paper ini adalah analisis regresi linear berganda yang mana dalam (Janie, 2012) dijelaskan bahwa regresi linear berganda digunakan untuk pengujian pengaruh dua atau lebih variabel independen terhadap variabel dependen. Variabel independennya adalah pengeluaran per kapita dengan alokasi anggaran dana kesehatan atau belanja kesehatan Kabupaten/Kota di pulau Jawa. Sedangkan variabel dependennya adalah angka kesakitan Kabupaten/Kota di Pulau Jawa. Data yang digunakan dalam penelitian paper ini adalah jenis data cross section dan dianalisis dengan bantuan aplikasi stata. 
Penelitian ini menggunakan data sekunder dari Data Statistik Kesejahteraan Seluruh Kab Kota di Pulau Jawa yang dikeluarkan oleh BPS DKI Jakarta, BPS Jawa Barat, BPS Banten, BPS Jawa Tengah, BPS Jawa Timur, dan BPS D.I.Yogyakarta (BPS Provinsi Banten, 2018; BPS Provinsi D.I. Yogyakarta, 2018; BPS Provinsi DKI Jakarta, 2018; BPS Provinsi Jawa Barat, 2018; BPS Provinsi Jawa Tengah, 2018; BPS Provinsi Jawa Timur, 2018). Penelitian ini juga menggunakan data Rincian Alokasi Transfer Ke Daerah dan Dana Desa ProvinsiKabupatenKota Dalam APBN tahun 2018 dari Kementrian Keuangan (Kementrian Keuangan RI, 2018). Penelitian ini berfokus pada melihat pengaruh antara pengeluaran per kapita wilayah tersebut dan alokasi dana kesehatan terhadap angka kesakitan wilayah tersebut. Penelitian ini menggunakan data cross section dan dianalisis dengan regresi linear berganda yang harus memenuhi asumsi klasik untuk mendapatkan estimator persamaan regresi. Dengan kriteria BLUE yaitu bebas multikolinearitas dan heterokedastisitas. Persamaan umum dari regresi linear berganda seperti yang dijelaskan dalam (Janie, 2012) dan (Widarjono, 2018) adalah sebagai berikut:

$$
\widehat{Y_{t}}=\widehat{\beta_{0}}+\beta_{1} \widehat{X 1_{1}}+\beta_{2} \widehat{X 2_{1}}++\widetilde{u_{z}}
$$

Keterangan:

$\mathbf{Y}_{\mathbf{t}}$ : Variabel dependen yang diestimasi.

$\boldsymbol{\beta}_{1}$ : Konstanta dari X1/variabel independen 1 atau nilai dari variabel independen 1 apabila tidak dipengaruhi oleh apapun.

$\boldsymbol{\beta}_{\mathbf{2}}$ : Konstanta dari X2/variabel independen 2 atau nilai dari variabel independen 2 apabila tidak dipengaruhi oleh apapun.

$\mathbf{X}_{\mathbf{1}}$ : Variabel independen ke 1

$\mathbf{X}_{2}$ : Variabel independen ke 2

$\mathbf{U}_{\mathbf{t}}$ : error

Didalam penelitian ini akan melakukan uji asumsi klasik yakni uji heteroskedastisitas dan uji multikolinearitas. Dalam (Widarjono, 2018) dijelaskan bahwa salah satu asumsi penting yang dibangun dalam model regresi adalah bahwa variannya bersifat homoskedastisitas. Ketika terlanggarnya asumsi ini tidak menyebabkan menunjukkan bahwa estimator ini bias. Heteroskedastisitas adalah kondisi dimana varians di observasi atau model yang diteliti tidak konstan. Heteroskedastisitas tidak menyebabkan estimator dalam model regresi penelitian ini bias dan tidak linear. Heteroskedastisitas ini menyebabkan error atau varians dalam model regresi ini menjadi bias, dan dampak lain dari heteroskedastisitas ini adalah menyebabkan biasnya matrik varians-kovarians yang digunakan untuk menghitung standard error. Jika varian tidak minim maka perhitungan standard error tidak bisa dipercaya kevaliditasannya. Jika dalam model tersebut tidak mempunyai varians yang konstan maka tidak akan mempengaruhi slope, tetapi hanya mempengaruhi intersep.

Berikut ini adalah kriteria dalam uji heteroskedastisitas:

Ho : Tidak terdapat masalah heteroskedastisitas

$\mathrm{Ha}$ : Terdapat masalah heteroskedastisitas

Kriteria:

Ho ditolak apabila $\mathrm{LM}>\mathrm{X}_{2 / \alpha}$ atau $p$-value $<\alpha$

Ho tidak dapat ditolak apabila $L M<X_{2 / a}$ atau $p$-value $>\alpha$ 
Multikolinearitas adalah hubungan linear antara variabel independen dalam model regresi. Adanya multikolinearitas masih menghasilkan estimator yang BLUE atau Best Linear Unbiased dan Estimator, tetapi jika suatu model regresi terdapat multikolinearitas maka akan mempunyai varians yang besar. Jika suatu model mempunyai standar error dan $\mathrm{t}$ yang rendah merupakan indikasi awal adanya masalah multikolinearitas. Gejala multikolinearitas yang lain adalah model mempunyai $\mathrm{R}^{2}$ atau koefisien determinasi yang tinggi tetapi hanya sedikit variabel independen yang signifikan. Untuk menguji apakah dalam model terdapat multikolinearitas dapat menggunakan command dalam stata (Widarjono, 2018).

Penelitian ini juga akan melakukan uji signifikasi yakni uji F-Test dan Uji t. Uji t atau dilakukan untuk mengamati tingkat signifikasi pengaruh dari masing-masing variabel independen atau variabel bebas terhadap variabel dependen atau variabel tidak bebas, dan variabel lain dianggap konstan atau tetap (cateris paribus) pada tingkat signifikasi $5 \%$ atau tingkat kepercayaan sebesar 95\%. Dengan tingkat signifikasi $5 \%$, $n$ adalah jumlah observasi, $\mathrm{k}$ jumlah variabel termasuk konstanta dan degree of freedom sebesar $\mathrm{df}=\mathrm{n}-\mathrm{k}$ (Widarjono, 2018). Hipotesis dari uji t dapat diamati sebagai berikut:

$\mathrm{H}_{0}: \beta_{1}=0$ (variable independen (bebas) secara parsial tidak berpengaruh terhadap variabel dependen (tidak bebas))

$\mathrm{H}_{\mathrm{a}}: \beta_{1} \neq 0$ (variabel independen (bebas) secara parsial berpengaruh terhadap variabel dependen (tidak bebas))

Kriterianya :

Jika t-test atau t-hitung lebih besar dari t-tabel (t-stat $>$ t-tabel) maka Ho ditolak dan Ha tidak dapat ditolak yang dapat diartikan bahwa variabel independen atau bebas secara parsial berpengaruh terhadap variabel dependen atau tidak bebas.

Jika $t$-test atau t-hitung lebih kecil dari t-tabel (t-stat < t-tabel) maka Ho tidak dapat di tolak dan $\mathrm{Ha}$ ditolak yang dapat diartikan bahwa variabel independen atau bebas secara parsial tidak berpengaruh terhadap variabel dependen atau tidak bebas.

Uji F-test atau F-hitung mengamati tingkat signifikasi pengaruh variabel independen atau variabel bebas secara bersama-sama terhadap variabel dependen atau variabel tidak bebas pada tingkat signifikasi $5 \%$ atau tingkat kepercayaan $95 \%$. Dengan tingkat signifikasi $5 \%, \mathrm{n}$ adalah jumlah observasi, $\mathrm{k}$ jumlah variabel termasuk konstanta dan degree of freedom sebesar $\mathrm{df}=\mathrm{n}-\mathrm{k}($ Widarjono, 2018). Hipotesis dari uji F-test dapat diamati sebagai berikut:

- $\quad \mathrm{H}_{0}: \beta_{1}, \ldots \beta_{\mathrm{n}}=0$ (variabel independen atau variabel bebas secara bersama-sama atau simultan tidak berpengaruh terhadap variabel dependen atau variabel tidak bebas)

- $\quad H_{1}: \beta_{1}, \ldots \beta_{n} \neq 0$ (variabel independen atau variabel bebas secara bersama-sama atau simultan berpengaruh terhadap variabel dependen atau variabel tidak bebas)

Kriteria :

Apabila F-test atau F-hitung lebih besar daripada F-tabel maka Ho tidak dapat ditolak atau yang dapat diartikan bahwa variabel independen atau variabel bebas secara bersama-sama atau simultan tidak berpengaruh terhadap variabel dependen atau variabel tidak bebas

Apabila F-test atau F-hitung lebih kecil daripada F-tabel maka Ho ditolak atau yang dapat diartikan bahwa variabel independen atau variabel bebas secara bersama-sama atau simultan tidak berpengaruh terhadap variabel dependen atau variabel tidak bebas. 


\section{Hasil Penelitian dan Pembahasan}

Berdasarkan data yang dikumpulkan dengan bersumber dari badan pusat statistik dan kementerian keuangan tahun 2018 per kabupaten dan kota. Untuk dataprovinsi DKI Jakarta terdapat 6 kabupaten/kota. Untuk data provinsi Jawa Barat terdapat 26 kabupaten/kota. Untuk data provinsi Banten terdapat 8 kabupaten/kota. Untuk data provinsi Jawa Tengah terdapat 32 kabupaten/kota. Untuk data provinsi Jawa Timur terdapat 36 kabupaten/kota. Untuk data provinsi DI Yogyakarta terdapat 5 kabupaten/kota. Berikut ini adalah hasil deskripsi statistik angka kesakitan, pengeluaran per kapita dan belanja kesehatan:

Tabel 1. Tabel Deskripsi Statistik

\begin{tabular}{|l|c|c|c|c|c|}
\hline \multicolumn{1}{|c|}{ Variabel } & Obs & Mean & Std. Dev. & Min & Max \\
\hline Angka Kesakitan (\%) & 113 & 14.33 & 3.72 & 6.75 & 27.04 \\
\hline Pengeluaran Per Kapita (ratusan ribu) & 113 & 11.09 & 4.2 & 4.55 & 26.52 \\
\hline Belanja Kesehatan (juta) & 113 & 22.28 & 11.93 & 3.45 & 64.70 \\
\hline
\end{tabular}

Dari data tabel 1 dapat diamati bahwa jumlah observasi dari penelitian ini adalah sebanyak 113 kabupaten/kota. Nilai minimum dari angka kesakitan adalah sebesar 6.75 persen, nilai maksimumnya adalah sebesar 27.04 persen, nilai rata-ratanya sebesar 14.33 persen dengan standar deviasi sebesar 3.72 persen. Nilai minimum dari pengeluaran perkapita adalah sebesar 454.719,6 rupiah, nilai maksimumnya adalah sebesar 2,652,362 rupiah, nilai rata-ratanya sebesar 1.109 .344 rupiah dengan standar deviasi sebesar 420,018.9 rupiah. Nilai minimum dari belanja kesehatan adalah sebesar 3,448,872 rupiah, nilai maksimumnya adalah sebesar 64.704 .450 rupiah, nilai rata-ratanya sebesar 22.278.070 rupiah dengan standar deviasinya sebesar 11.925.560 rupiah.

\section{Angka kesakıtan ${ }_{i}={\widetilde{\beta_{0}}}+\widehat{\beta}_{1}$ pengeluaran $_{i}+\beta_{2}$ belanjakesehatan $_{i}++\widetilde{u}_{i}$}

\section{Angka kesakutan}

$$
\begin{aligned}
& =18.12196-0.3352448 \text { pengeluaran } \\
& -0.0031807 \text { belanjakesehatan }{ }_{t}+\widehat{u}_{\imath}
\end{aligned}
$$

Dengan hasil regresi tersebut menunjukkan setiap pengeluaran per kapita meningkat sebesar Rp. 1.000.000,00 maka angka kesakitan akan bertkurang sebesar 0.03352448 . dan setiap kenaikan belanja kesehatan sebesar Rp. Rp. 10.000.000,00 maka angka kesakitan akan berkurang sebesar 0.0031007 . $R^{2}$ pada regresi ini sebesar $14.47 \%$ yang dapat diartikan bahwa variabel independen yakni pengeluaran per kapita dan belanja kesehatan dapat mempengaruhi angka kesakitan sebesar $14.47 \%$ sedangkan $85.53 \%$ nya dipengaruhi oleh variabel lain diluar model.

\section{A. Uji Multikolinearitas}

Tabel 2. Hasil Uji Multikolinearitas

\begin{tabular}{|l|c|c|}
\hline \multicolumn{1}{|c|}{ Variabel } & VIF & 1/VIF \\
\hline Pengeluaran Per Kapita & 1.02 & 0.984066 \\
\hline Belanja Kesehatan & 1.02 & 0.984066 \\
\hline Mean VIF & 1.02 & \\
\hline
\end{tabular}

Ho: Tidak terdapat multikolinearitas

Ha: Terdapat Multikolinearitas

Kriteria: mean VIF $\geq 5$ maka Ho ditolak

mean $\mathrm{VIF} \geq 10$ maka Ho ditolak

mean VIF $<10$ dan 1/VIF $>0.1$ maka Ho diterima

Mean VIF $<10$

$1.02<10$

Jadi, dapat disimpulkan bahwa tidak terdapat masalah multikolinearitas dalam model tersebut. 


\section{B. Uji Heteroskedastisitas}

Breusch - Pagan Test for heteroskedasticity

Chi2 $(1) \quad=2.96$

Prob $>$ chi2 $=0.0853$

Ho: Tidak terdapat heteroskedastisitas

Ha: Terdapat heteroskedastisitas

Kriteria: Ho ditolak apabila LM $>\mathrm{X}_{2 / \alpha}$ atau $p$-value $<\alpha$

Ho diterima apabila $L M<X_{2 / \alpha}$ atau $p$-value $>\alpha$

Karena $L M<X_{2 / \alpha}=2.96<5.991$ maka Ho diterima

Jadi, dapat disimpulkan bahwa dengan tingkat signifikasi $5 \%$ terdapat cukup bukti bahwa tidak terdapat masalah heteroskedastisitas.

C. Uji F-Test

Ho: $\beta_{1}=\beta_{2}=0$ (tidak terdapat pengaruh variabel independen secara simultan terhadap variabel dependen)

Ha: setidaknya ada 1 nilai $\beta_{i} \neq 0$ (minimal ada 1 variabel independen yang mempengaruhi variabel dependen)

Kriteria: F-stat $\leq F$ - table : Ho tidak dapat ditolak

$\mathrm{Df} 1=\mathrm{k}=2$

F-stat $>$ F- table : Ho ditolak

Df2 $=\mathrm{n}-\mathrm{k}-1=110$

F-stat $=\frac{R^{2} / k}{\left(1-R^{2}\right) /(n-k-1)}$

$$
=\frac{0,1447 / 2}{(0,8553) /(113-2-1)}
$$

$=9.30492225$

F-tabel $=2.9957$

$\alpha=5 \%=0,05$

\section{F-stat > F-tabel}

\section{$9.30492225>2.9957$, maka Ho ditolak}

Jadi, dengan tingkat signifikasi 5\% karena Ho ditolak maka dapat disimpulkan bahwa terdapat pengaruh yang signifikan variabel pengeluaran per kapita dan belanja kesehatan secara bersama-sama terhadap variabel angka kesakitan, cateris paribus.

\section{Uji t-test}

Ho: $\beta_{1}=0$ (tidak terdapat pengaruh variabel pengeluaran per kapita terhadap angka kesakitan)

$\mathrm{Ha}: \beta_{1} \neq 0$ (terdapat pengaruh variabel pengeluaran per kapita terhadap angka kesakitan)

Kriteria: $t$-stat $\leq \mathrm{t}$ - tabel maka Ho tidak dapat ditolak

$t$-stat $>$ t- tabel maka Ho ditolak

$\mathrm{Df}=\mathrm{n}-\mathrm{k}-1=110$

$$
\begin{aligned}
\text { t-stat } & =\frac{\beta \mathrm{n}-\beta 0}{S E(\beta \mathrm{n})} \\
& =\frac{0.3352448-0}{0.0786482} \\
& =4.240713456 \\
\text { t-tabel } & =1.960
\end{aligned}
$$

$\alpha=5 \%=0,05$ 
Jadi, dengan tingkat signifikasi 5\% karena Ho ditolak maka dapat disimpulkan bahwa terdapat pengaruh yang signifikan variabel pengeluaran per kapita terhadap angka kesakitan.

Ho: $\beta_{1}=0$ (tidak terdapat pengaruh variabel belanja kesehatan terhadap angka kesakitan)

$\mathrm{Ha}: \beta_{1} \neq 0$ (terdapat pengaruh variabel belanja kesehatan terhadap angka kesakitan)

Kriteria: $\mathrm{t}$-stat $\leq \mathrm{t}$ - tabel maka Ho tidak dapat ditolak

t-stat $>$ t- tabel maka Ho ditolak

$\mathrm{Df}=\mathrm{n}-\mathrm{k}-1=110$

t-stat $=\frac{\beta n-\beta 0}{S E(\beta n)}$

$$
=\frac{0.0031807-0}{0.0276999}
$$

$=0.1148271233$

t-tabel $=1.960$

$\alpha=5 \%=0,05$

t-stat $<$ t-tabel

$0.1148271233<1.960$, maka Ho ditolak.

Jadi, dengan tingkat signifikasi $5 \%$ karena Ho tidak dapat ditolak maka dapat disimpulkan bahwa tidak terdapat pengaruh yang signifikan variabel belanja kesehatan terhadap angka kesakitan.

\section{IV.Kesimpulan}

Dapat disimpulkan bahwa pengeluaran per kapita terhadap angka kesakitan di kabupaten-kota di pulau Jawa mempunyai hubungan yang negatif dan signifikan. Artinya penambahan pengeluaran per kapita akan mengakibatkan penurunan angka kesakitan di daerah tersebut. Hal ini dikarenakan pengeluaran per kapita merupakan indikator kualitas gizi makanan masyarakat di daerah tersebut bagus atau tidak sehingga ketika pengeluaran tinggi maka gizi yang dikonsumsi oleh masyarakat juga tinggi yang mana akan menyebabkan seseorang tidak mudah terkena penyakit. Dan juga ketika seseorang mempunyai pengeluaran yang tinggi, ia akan mudah mendapatkan akses ke rumah sakit atau berobat. Ketika mayoritas masyarakat di suatu daerah mempunyai pengeluaran per kapita yang tinggi maka secara signifikan akan mengurangi angka kesakitan di daerah tersebut. Untuk belanja kesehatan atau alokasi anggaran dana kesehatan mempunyai hubungan yang negatif tetapi tidak signifikan terhadap angka kesakitan di kabupaten-kota di pulau Jawa. Dalam (Sihaloho \& Hardiawan, 2019) bahwa belanja kesehatan akan berpengaruh positif terhadap angka harapan hidup dan angka harapan hidup yang baik ditunjukkan juga dengan angka kesakitan yang rendah. Ketika pemerintah daerah setempat memprioritaskan anggarannya untuk pembangunan kesehatan maka pemerintah akan menggunakannya untuk memperbaiki kualitas tempat berobat atau kualitas tenaga kesehatan atau memberikan pengobatan gratis kepada masyarakat yang mana akan menurunkan angka kesakitan didaerah tersebut. Dalam (Aryani, 2007) alokasi anggaran dana kesehatan yang mempunyai hubungan yang tidak signifikan dapat dikarenakan alokasi dana kesehatan tidak menyentuh ke pelayanan langsung kepada masyarakat. Realisasi penurunan alokasi anggaran dana kesehatan banyak kendala sehingga dinas kesehatan susah untuk mencairkan uangnya. Dijelaskan pula faktor yang sangat mempengaruhi pada proses impelementasi dana kesehatan adalah terlalu lamanya penetapan besar dana anggaran. Turunnya dana alokasi kesehatan dari pemerintah daerah dipengaruhi oleh tepat dan cepatnya jadwal pelaksanaan dan besaran dana. Jika salah satu faktor diatas terlambat pengerjaannya maka lambat pula penurunan dana alokasi kesehatannya. 


\section{Daftar Pustaka}

Alisjahbana, A. S. (2003). Analisis Ekonomi Jawa Barat. Bandung: Unpad Press.

Amrullah, F. (2015). Aplikasi Kebijakan Jaminan Kesehatan di Jatinangor. Prosiding-KS: Penelitian Dan Pengabdian Kepada Masyarakat, 2(2), 147-300.

Arida, A. (2015). Analisis Ketahanan Pangan Rumah Tangga Berdasarkan Proporsi Pengeluaran Pangan dan Konsumsi Energi. Jurnal Agrisep, 16(1), 20-34.

Aryani, N. (2007). Analisis Pembiayaan Kesehatan Bersumber Pemerintah di Kabupaten Bogor. Jurnal Kesehatan Masyarakat Nasional., 2(1), 39-48.

Augustyn, G. H. (2002). Pola Konsumsi Pangan dan Status Gizi Anak Usia Balita Pengungsi di Desa Waraka Kecamatan Amahai Provinsi Maluku. In Community Nutrition and Family Studies (Vol. 26, pp. 17-21). Ambon: Fakultas Pertanian.

BPS Provinsi Banten. (2018). Statistik Kesejahteraan Rakyat Kabupaten dan Kota di Banten 2018.

BPS Provinsi D.I. Yogyakarta. (2018). Statistik Kesejahteraan Rakyat Kabupaten dan Kota di D.I.Yogyakarta 2018.

BPS Provinsi DKI Jakarta. (2018). Statistik Kesejahteraan Rakyat DKI Jakarta 2018.

BPS Provinsi Jawa Barat. (2018). Statistik Kesejahteraan Rakyat Kabupaten dan Kota di Jawa Barat 2018.

BPS Provinsi Jawa Tengah. (2018). Statistik Kesejahteraan Rakyat Kabupaten dan Kota di Jawa Tengah 2018.

BPS Provinsi Jawa Timur. (2018). Statistik Kesejahteraan Rakyat Kabupaten dan Kota di Jawa Timur 2018.

Budiarto, E. (2001). Pengantar Epidemiologi (2nd ed.). Jakarta: Penerbit Buku Kedokteran EGC.

Efendi, F. (2009). Keperawatan Kesehatan Komunitas. Jakarta: Salemba Medika.

Handayani, T. (2016). Analisis Pembiayaan Kesehatan Daerah Bersumber Publik: Studi Kasus di Dinas Kesehatan Kabupaten Bogor Tahun 2012, 2013 dan 2014. Jurnal Ekonomi Kesehatan Indonesia, 1(2), 35-43.

Hidayat, A. A. (2008). Pengantar Ilmu Kesehatan Anak. Jajkarta: Salemba Medika.

Janie, D. N. A. (2012). Statistik Deskriptif \& Regresi Linearj Berganda Dengan SPSS. Semarang: Semarang University Press.

Kardjati, S. (1985). Aspek Kesehatan dan Gizi Anak Balita.j (1st ed.). Jakarta: Yayasan Obor Indonesia.

Kementerian Keuangan. (2017). Informasi APBN. Kementerian keuangan.

Kementerian Keuangan. (2018). Informasi APBN. Kementerian keuangan. 
Kementerian Keuangan. (2019). Informasi APBN. Kementerian keuangan.

Kementrian Keuangan RI. (2018). Rincian Alokasi Transfer Ke Daerah dan Dana Desa ProvinsiKabupatenKota Dalam APBN T.A 2018, 1-18.

Marmi. (2013). Gizi Dalam Kesehatan Reproduksi. Yogyakarta: Pustaka Pelajar.

Mulazimmah. (2017). Hubungan Pendapatan Keluarga Dengan Status Gizi Balita Desa Ngadiluwih Kecamatan Ngadiluwih Kabupaten Kediri. Jurnal Efektor, 4(2), 18-21.

Muliza. (2017). Analisis Pengaruh Belanja Pendidikan, Belanja Kesehatan, Tingkat Kemiskinan, dan PDRB Terhadap IPM di Provinsi Aceh. Jurnal Perspektif Ekonomi Darussalam, 3(1), 51-69.

Notowidagdo, R. (2016). Pengantar Kesejatraan Sosial Berwawasan Iman dan Takwa. Jakarta: AMZAH.

Olivia, S. (2010). Analisis Politik dan Kebijakan Pembiayaan Rumah Sakit Pemerintah DKI Jakarta. Jurnal Kesehatan Masyarakat Nasional, 5(3), 116-124.

Prasetyo, W. E. (2013). Hubungan Antara Tingkat Pendapatan dan Pengeluaran Pangan dan Non-Pangan Keluarga Dengan Status Gizi Anak Pra Sekolah di Kelurahan Semanggi dan Sangkrah, Kecamatan Pasar Kliwon, Surakarta. Universitas Muhammadiyah Surakarta.

Rachmat, H. H. (2016). Penguatan Upaya Kesehatan Masyarakat dan Pemberdayaan Masyarakat Bidang Kesehatan di Indonesia. Yogyakarta: Gadjah Mada University Press.

Sihaloho, E. D., \& Hardiawan, D. (2019). Pengaruh Belanja Kesehatan dan Angka Kemiskinan Terhadap Angka Harapan Hidup Kabupaten Kota di Jawa Barat. Ekspansi: Jurnal Ekonomi, Keuangan, Perbankan Dan Akuntansi, 11(1), 117-128. https://doi.org/10.35313/ekspansi.v11i1.1308

Sitorus, E. (2017). Analisis Pembiayaan Kesehatan Bersumber Pemerintah di Kota Serang Tahun 2014-2016. Jurnal Kebijakan Kesehatan Indonesia, 06(3), 138-148.

Soenardi, T. (2010). Variasi Makanan Balita. Jakarta: PT. Gramedia Pustaka Utama.

Suarsih, S. (2017). Analisis Kebijakan Dana Desa untuk Pembangunan Kesehatan di Kabupaten Malinau dengan Pendekatan Segitiga Kebijakan. Jurnal Sistem Kesehatan, 2(4), 211-217.

Sulastomo. (2007). Manajemen Kesehatan (3rd ed.). Jakarta: PT Gramedia Pustaka Utama.

Syamsurijal. (2008). Pengaruh Tingkat Kesehatan dan Pendidikan Terhadap Tingkat Pertumbuhan Pendapatan per Kapita di Sumatera Selatan. Jurnal Ekonomi Pembangunan, 6(1), 1-9.

Tuankotta, K. (2012). Hubungan Pengeluaran Rumah Tangga untuk Makanan Dengan Kecukupan Total Asupan Energi Anak Usia 24-59 Bulan di Provinsi Jawa Barat Tahun 2010. Universitas Indonesia.

Widarjono, A. (2018). Ekonometrika: Pengantar dan Aplikasinya Disertai Panduan Eviews Edisi 5 (5th ed.). Yogyakarta: UPP STIM YKPN. 